\title{
Multiplikasi Tunas In Vitro Anggrek Phalaenopsis dan Analisis Keragaman Genetik dengan Marka SNAP
}

\section{In Vitro Shoot Multiplication of Phalaenopsis Orchid and Genetic Diversity Analysis using SNAP Markers}

\author{
Mira Humaira ${ }^{1}$, Agus Purwito ${ }^{2}$, Sudarsono ${ }^{2}$, dan Dewi Sukma ${ }^{2 *}$ \\ ${ }^{1}$ Program Studi Pemuliaan dan Bioteknologi Tanaman, Sekolah Pascasarjana, Institut Pertanian Bogor \\ ${ }^{2}$ Departemen Agronomi dan Hortikultura, Fakultas Pertanian, Institut Pertanian Bogor \\ (Bogor Agricultural University), Jl. Meranti, Kampus IPB Darmaga, Bogor 16680, Indonesia
}

Diterima 17 Januari 2020/Disetujui 17 April 2020

\begin{abstract}
Clonal propagation of orchid by in vitro culture is needed to obtain the high quantity and quality of orchid propagules. This study aimed to understand the effect of BAP (benzyl amino purine) concentrations on the shoot multiplication of three Phalaenopsis hybrid populations and to analyze genetic diversity of the clonal shoot population using Pto-SNAP markers. The experiments were performed separately for each population, namely shoots from seed germination of Phal. amabilis $x$ Phal. 'KHM 421' multiplicated on media with four levels of BAP $(0.00,11.09,22.19,33.29,44.39 \mu M)$, clonal shoots from Phal. 'Salu Spot'x Phal. bellina '1102-38', and Phal. 'Salu Spot'x Phal. bellina '1102-44' with four level of BAP (11.09, $22.19,33.29,44.39 \mu M)$. The results showed that the optimum BAP concentration for shoot multiplication for the three populations was $22.19 \mu \mathrm{M}$ which generated an average of 3.7, 4.7, and 6.0 shoots per explant at 12 week after planting (WAP) for each of the tested population. Protocorm like bodies (PLBS) was only produced on Phal. amabilis $x$ Phal. 'KHM 421' population and the highest number of PLBs was obtained on medium containing 11.09 BAP. Evaluation of genetic diversity was performed using 11 Pto-SNAP markers for shoots of Phal. 'Salu Spot'x Phal. bellina '1102-44'. The results revealed the presence of 7.7\% somaclonal variation at the Pto-241 locus among shoots from medium containing BAP 22.19 $u M$ and $11.1 \%$ at the Pto 424 locus among those from medium with BAP 44.39 uM, respectively.
\end{abstract}

Keywords: clonal propagation, cytokinin, molecular markers, Pto, somaclonal variation

\section{ABSTRAK}

Perbanyakan klonal anggrek melalui kultur in vitro dibutuhkan untuk memperoleh sejumlah besar propagul tanaman yang berkualitas. Tujuan dari penelitian ini adalah untuk mengetahui pengaruh konsentrasi BAP terhadap kemampuan multiplikasi tunas dalam propagasi klonal beberapa anggrek hibrida Phalaenopsis dan menganalisis keragaman genetik pada tunas klonal menggunakan marka Pto-SNAP. Percobaan dilakukan secara terpisah pada 3 populasi tunas anggrek hibrida Phalaenopsis yaitu, tunas hasil perkecambahan biji dari Phal. amabilis $x$ Phal. 'KHM 421'diperbanyak dalam media dengan 5 taraf BAP $(0.00,11.09,22.19,33.29,44.39 \mu M)$, dan tunas klon Phal. 'Salu Spot'x Phal. bellina '1102-38' dan Phal. 'Salu Spot'x Phal. bellina '1102-44' diperbanyak dalam media dengan 4 taraf BAP (11.09, 22.19, 33.29, $44.39 \mu M)$. Hasil penelitian menunjukkan bahwa konsentrasi BAP terbaik untuk multiplikasi tunas pada tiga populasi yang diuji adalah $22.19 \mu \mathrm{M}$ dengan jumlah tunas masing-masing 3.7, 4.7, dan 6.0 tunas pada 12 minggu setelah tanam (MST). Protocorm like bodies (PLBS) hanya dihasilkan pada populasi Phal. amabilis $x$ Phal. 'KHM 421' dengan jumlah PLBs terbanyak diperoleh pada perlakuan BAP $11.09 \mu$ M. Evaluasi keragaman genetik menggunakan 11 marker Pto-SNAP dilakukan pada tunas klonal Phal. 'Salu Spot'x Phal. bellina '1102-44'. Hasil analisis menunjukkan adanya variasi somaklonal dengan keragaman $7.7 \%$ pada lokus Pto-241 pada tunas dari media perlakuan BAP $22.19 \mu$ M dan 11.1\% pada lokus Pto-424 pada tunas dari media dengan BAP $44.39 \mu M$.

Kata kunci: marka molekuler, propagasi klonal, Pto, sitokinin, variasi somaklonal

\footnotetext{
* Penulis untuk korespondensi. e-mail: dewi_sukma@apps.ipb.ac.id
} 


\section{PENDAHULUAN}

Anggrek (Famili Orchidaceae) merupakan salah satu famili tanaman berbunga terbesar, terdiri 6 sub famili dan 19,000-24,000 spesies (Cetzal et al., 2014). Diperkirakan lebih dari 4,000 spesies anggrek terdapat di wilayah Indonesia (Handoyo dan Prasetya, 2009). Phalaenopsis merupakan salah satu genus anggrek yang populer yang banyak digemari oleh masyarakat karena memiliki nilai estetika tinggi, dengan warna dan bentuk bunga yang beragam, vase life yang panjang dan harga yang relatif stabil dan terjangkau oleh masyarakat. Pengembangan agribinis anggrek sering terkendala karena terbatasnya ketersediaan bibit dari varietas unggul baru yang berkualitas (Gow et al., 2009). Kontribusi nilai impor bibit anggrek di Indonesia mencapai $61.57 \%$ dari total nilai impor anggrek di Indonesia (Pusat Data dan Sistem Informasi Pertanian, 2015).

Salah satu alternatif untuk mempercepat pertumbuhan serta memenuhi kebutuhan bibit anggrek dalam jumlah yang banyak dan seragam adalah melalui induksi tunas aksilar dalam teknik kultur jaringan (Jones dan Tisserat, 1990; Kosir et al., 2004; Yuswanti et al., 2015) atau induksi protocorm like bodies (PLBs) dari protokorm atau eksplan daun (Paek et al., 2011; Rittirat et al., 2012; Raynalta et al., 2013; Raynalta et al., 2018). Eksplan yang umumnya digunakan untuk memperbanyak tunas anggrek Phalaenopsis secara vegetatif adalah tangkai bunga yang mengandung mata tunas dorman (Kosir et al., 2004; Dwiyani, 2012; Yuswanti et al., 2015). Keberhasilan dalam induksi tunas baru dari tangkai bunga sangat dipengaruhi oleh zat pengatur tumbuh, diantaranya auksin dan sitokinin (Balilashaki et al., 2014). Sitokinin berfungsi dalam pembelahan sel, morfogenesis pada kultur jaringan, pertumbuhan tunas lateral, ekspansi daun, menghambat senesen daun, dan memacu inisiasi tunas (Davies, 2004; Restiani et al., 2016). Alternatif lain dalam perbanyakan anggrek adalah melalui induksi protocorm like bodies (PLBs). PLBs merupakan struktur yang menyerupai protocorm yang diinduksi dari eksplan protocorm atau potongan daun (Balilashaki et al., 2014; Raynalta et al., 2018). Perkembangan PLBs didefinisikan sebagai proses embryogenesis somatic karena protocorm merupakan fase perkembangan lanjut dari embrio (Lee et al., 2013). Perkembangan PLBs pada Phalaenopsis dipengaruhi oleh berbagai faktor diantaranya zat pengatur tumbuh dan bahan organik (Raynalta dan Sukma, 2013; Yulianti et al., 2016; Raynalta et al., 2018).

Penerapan metode mikropropagasi klonal in vitro pada anggrek Phalaenopsis memiliki beberapa kelemahan, salah satunya adalah variasi somaklonal pada bibit hasil perbanyakan (Chen dan Chen, 2007; Chen et al., 2008). Deteksi dini adanya variasi somaklonal dapat membantu proses seleksi propagul yang true to type. Menurut Bairu et al. (2011), variasi somaklonal maka dapat diketahui dengan aplikasi marka molekuler. Salah satu marka molekuler yang populer akhir-akhir ini adalah marka SNAP (single nucleotide amplified polymorphic). Marka SNAP merupakan penanda genetik yang dikembangkan berdasarkan pada single nucleotide polymorphism (SNP, keragaman satu basa nukleotida) pada sekuen gen tertentu pada tanaman (Mammadov et al., 2012). Pada anggrek Phalaenopsis, Elina et al. (2017) telah mengkarakterisasi dan mengidentifikasi keberadaan SNP dari gen Pto. Gen Pto merupakan salah satu gen ketahanan tanaman terhadap patogen bakteri yang ditemukan pada tanaman tomat (Sun et al., 2011). Sukma et al. (2017) dan Raynalta et al. (2018) telah menggunakan beberapa marka Pto-SNAP untuk analisis keragaman tunas klonal asal PLBs anggrek Phal. amabilis. Penelitian ini bertujuan untuk: (1) mengevaluasi pengaruh konsentrasi BAP terhadap multiplikasi tunas tiga genotipe anggrek hibrida Phalaenopsis, (2) menganalisis keragaman genetik menggunakan marka molekuler PtoSNAP pada tunas klonal hasil multiplikasi in vitro.

\section{BAHAN DAN METODE}

Penelitian dilaksanakan pada bulan Maret 2018 sampai dengan Maret 2019 di Laboratorium Kultur Jaringan 1 dan Laboratorium Biologi Molekuler Tanaman, Departemen Agronomi dan Hortikultura, Fakultas Pertanian, Institut Pertanian Bogor. Penelitian ini terdiri dari dua tahap, tahap 1 adalah multiplikasi tunas tiga genotipe hibrida anggrek Phalaenopsis pada berbagai konsentrasi BAP in vitro. Percobaan dilakukan terpisah pada populasi tanaman yaitu tunas hasil perkecambahan biji hasil persilangan Phal. amabilis x Phal. 'KHM 421', tunas klon Phal. 'Salu Spot' x Phal. bellina '1102-38', dan Phal. 'Salu Spot' x Phal. bellina '1102-44'. Tunas klon Phal. 'Salu Spot' x Phal. bellina '1102-38' dan Phal. 'Salu Spot' x Phal. bellina '1102-44' diinisiasi dan diinduksi dari eksplan awal mata tunas dorman pada buku dari tangkai bunga dan diperbanyak di $1 / 2$ konsentrasi media MS ( $1 \frac{1}{2}$ MS) dengan BAP $11.09 \mu \mathrm{M}$ hingga diperoleh jumlah tunas yang cukup untuk percobaan. Tunas Phal. amabilis x Phal. 'KHM 421' berasal dari hasil perkecambahan benih sehingga terdapat kemungkinan secara genetik bahan tanaman bervariasi.

Rancangan percobaan yang digunakan adalah rancangan acak lengkap (RAL) satu faktor perlakuan yaitu konsentrasi BAP. Media dasar yang digunakan untuk multiplikasi tunas adalah $1 / 2$ MS ditambah $0.53 \mu \mathrm{M}$ NAA (1 $\left.\mathrm{mg} \mathrm{L}^{-1}\right)$, air kelapa muda $10 \%(\mathrm{v} / \mathrm{v})$, pepton $1 \mathrm{~g} \mathrm{~L}^{-1}$, dan PVP $0.5 \mathrm{~g} \mathrm{~L}^{-1}$. Perlakuan konsentrasi BAP sebagai berikut : $0 \mu \mathrm{M}, 11.09 \mu \mathrm{M}, 22.19 \mu \mathrm{M}, 33.29 \mu \mathrm{M}$, dan $44.39 \mu \mathrm{M}$ atau 0.0, 2.5, 5.0, 7.5 dan $10.0 \mathrm{mg} \mathrm{L}^{-1}$ BAP untuk Phal. amabilis x Phal. 'KHM 421' dan $11.09 \mu$ M, $22.19 \mu$ M, 33.29 $\mu$ M, dan $44.39 \mu \mathrm{M}$ untuk Phal. 'Salu Spot' x Phal. bellina '1102-38' dan Phal. 'Salu Spot' x Phal. bellina '1102-44'. Volume media per botol kultur sebanyak $20 \mathrm{ml}$. Eksplan awal berupa tunas tunggal ditanam pada media perlakuan. Peubah yang diamati adalah jumlah tunas, jumlah daun, jumlah akar, dan jumlah PLBs per sampel pengamatan (per botol) pada 2 sampai 12 MST. Setiap perlakuan terdiri atas tiga ulangan dan tiap ulangan terdiri dari 10 tunas dengan satu tunas per botol. Analisis data menggunakan perangkat lunak STAR (Statistical Tool for Agricultural Research). Apabila hasil uji F-nyata maka dilakukan uji Duncan's Multiple Range Test (DMRT) dengan $\alpha 5 \%$. 
Pada tahap 2, dilakukan uji Pto-SNAP marker untuk analisis keragaman genetik secara molekuler pada 30 tunas klonal hasil perlakuan BAP dari Phal. 'Salu Spot' x Phal. bellina '1102-44', untuk menghindari bias keragaman planlet antar perlakuan yang dapat bersumber dari segregasi jika menggunakan planlet asal biji dari Phal. amabilis x Phal. 'KHM 421'. DNA diisolasi 30 tunas klonal dari tanaman F1 Phal. 'Salu Spot' x Phal. bellina '1102-44', menggunakan metode CTAB (Doyle dan Doyle, 1987) yang dimodifikasi oleh Elina et al. (2017). DNA yang dihasilkan selanjutnya diamplifikasi PCR dengan 11 primer Pto-SNAP (Pto-64, Pto-94, Pto-181, Pto-220, Pto-229, Pto-241, Pto-292, Pto-340, Pto-349, Pto-380, dan Pto424 mengikuti metode yang telah dioptimasi Sukma et al. (2017) dan Raynalta et al. (2018). Produk amplifikasi PCR dielektroforesis pada gel agarose $2 \%$ selama 35 menit (50 V). Data visual dari elektroforesis dikonversi menjadi data alelik berdasarkan kemunculan pita dan jenis pasang basa (reference dan alternate) pada masing-masing lokus. Skor yang diperoleh digunakan untuk mendapatkan persentase keragaman antar klon.

\section{HASIL DAN PEMBAHASAN}

\section{Jumlah Tunas, Daun, Akar, dan PLBs}

Hasil analisis ragam dan rata-rata jumlah tunas, daun, akar, dan PLBs pada populasi hibrida Phal. amabilis x Phal.'KHM 421' disajikan pada Tabel 1. Pada populasi genotipe tersebut, BAP berpengaruh nyata terhadap jumlah, tunas, daun, akar, dan PLBs. Perlakuan 22.19 $\mu \mathrm{M}$ BAP (5 $\mathrm{mg} \mathrm{L}^{-1}$ ) menghasilkan jumlah tunas dan daun terbanyak yaitu 3.7 tunas dan 7 daun pada 12 MST. Hasil tersebut menunjukkan tunas yang terbentuk mengalami morfogenesis daun yang normal sehingga jumlah daun yang dihasilkan maksimal. Keragaan tunas pada penelitian disajikan pada Gambar 1A-E.

Akar mulai terbentuk pada saat 2 MST pada semua komposisi media. Konsentrasi BAP cenderung menekan jumlah akar, sehingga jumlah akar terbanyak dihasilkan pada media tanpa BAP (kontrol) sebesar 3.3 akar pada 12 MST. Pada media perlakuan lainnya yang mengandung BAP, jumlah akar lebih rendah, namun tidak berbeda nyata antar 4 konsentrasi BAP. Media dasar dari semua perlakuan mengandung $0.53 \mu \mathrm{M}$ NAA, sehingga pada media tanpa BAP, rasio auksin dan sitokinin menjadi lebih tinggi dan meningkatkan jumlah akar.

Protocorm like bodies (PLBs) pada populasi Phal. amabilis x Phal.'KHM 421' percobaan ini mulai terbentuk pada dasar tunas pada saat $8 \mathrm{MST}$. Konsentrasi BAP berpengaruh nyata terhadap jumlah PLBs, dengan jumlah PLBs terbanyak (3.7 PLBs) dihasilkan pada konsentrasi $11.09 \mu \mathrm{M}$ BAP pada $12 \mathrm{MST}$. PLBs terlihat sebagai struktur seperti nodul pada dasar tunas, seperti terlihat pada gambar 1F-J.

Rata-rata jumlah tunas, daun dan akar pada dan daun terbanyak pada Phal. 'Salu Spot' $x$ Phal. bellina '110238' seperti terlihat pada Tabel 2. Jumlah tunas dan daun terbanyak pada genotipe tersebut diperoleh pada perlakuan
$22.19 \mu$ M BAP sebanyak 4.7 tunas dan 7.0 pada 12 MST. Rata-rata jumlah akar tidak berbeda nyata antar perlakuan, yaitu sekitar 2-3 akar per eksplan. Sebaliknya PLBs tidak dihasilkan pada tunas dari semua perlakuan konsentrasi BAP.

Rata-rata jumlah tunas, daun dan akar pada dan daun terbanyak pada Phal. 'Salu Spot' $x$ Phal. bellina '110244' seperti terlihat pada Tabel 3. Hasil analisis ragam menunjukkan bahwa perlakuan konsentrasi BAP pada Phal. 'Salu Spot' $x$ Phal. bellina '1102-44' berpengaruh nyata terhadap jumlah tunas, daun pada 6 hingga 12 MST, namun tidak berpengaruh nyata terhadap jumlah akar. Jumlah tunas dan daun terbanyak pada Phal. 'Salu Spot' x Phal. bellina '1102-44' juga diperoleh pada perlakuan 22.19 $\mu \mathrm{M}$ BAP, sebanyak 6.0 tunas dan 7.7 daun pada 12 MST. Sebaliknya jumlah akar tidak berbeda nyata antar perlakuan BAP, yaitu sekitar 1-2 akar per eksplan. Tunas pada semua perlakuan juga tidak menghasilkan PLBs seperti pada Phal. 'Salu Spot' x Phal. bellina '1102-38'.

Multiplikasi tunas pada ketiga genotipe tanaman yang diuji menunjukkan respon yang relatif sama, yaitu jumlah tunas terbanyak dihasilkan pada perlakuan $22.19 \mu \mathrm{M}$ BAP (5.0 mg L-1). Kosir et al. (2004) melaporkan multiplikasi terbanyak tunas Phalaenopsis sp. diperoleh pada $0.5 \mathrm{mg}$ $\mathrm{L}^{-1} \mathrm{NAA}$ dan $2.0 \mathrm{mg} \mathrm{L}^{-1}$ BAP dengan faktor multiplikasi sebesar 8.35 dalam waktu 160 hari setelah pengkulturan. Sementara Balilashaki et al. (2014) mendapatkan regenerasi tunas terbaik pada Phalaenopsis 'Cool Breeze' yaitu $1 \mathrm{mg} \mathrm{L}^{-1} \mathrm{NAA}$ dan $4 \mathrm{mg} \mathrm{L}^{-1}$ BAP dengan jumlah tunas yang diperoleh sebanyak 15.3 tunas. Jumlah tunas yang diperoleh pada 3 genotipe yang diuji dalam penelitian masih lebih rendah dibanding yang dihasilkan Kosir et al. (2004) dan Balilashaki et al. (2014), walaupun keduanya pada genotipe tanaman yang berbeda. Jumlah tunas kemungkinan masih dapat ditingkatkan dengan mengoptimalkan beberapa faktor lain selain konsentrasi BAP, seperti Balilashaki et al. (2014) mendapatkan tunas terbanyak dengan memodifikasi media 1/2MS mengikuti Chen et al. (1999), yaitu dengan menambahkan NaH2PO4 $170 \mathrm{mg} \mathrm{L}^{-1}$, pepton $2 \mathrm{mg} \mathrm{L}^{-1}$ dan mengganti agar dengan gelrite dan menurunkan konsentrasi sukrosa menjadi $20 \mathrm{~g} \mathrm{~L}^{-1}$. Penambahan bahan organik ekstrak toge dilaporkan dapat mendorong multiplikasi tunas in vitro Phal. gigantea (Ramdan, 2011).

Kemampuan multiplikasi tunas pada ketiga genotipe tanaman tidak diuji statistik karena percobaan dilakukan secara terpisah, namun terlihat kecendrungan bahwa genotype Phal. 'Salu Spot' x Phal. bellina '1102-38' dan Phal. 'Salu Spot' x Phal. bellina '1102-44' menghasilkan jumlah tunas yang lebih banyak dari populasi tunas Phal. amabilis x Phal. 'KHM 421'. Demikian juga antara Phal. 'Salu Spot' x Phal. bellina '1102-38' dan Phal. 'Salu Spot' x Phal. bellina '1102-44'. Meskipun berasal dari tetua yang sama, daya multiplikasinya berbeda, menunjukkan adanya perbedaan genetik antara kedua genotipe tersebut. Perbedaan genetik tersebut juga terlihat secara visual dari perbedaan morfologi tunas seperti terlihat pada Gambar 2. Tunas-tunas dari Phal. amabilis x Phal. 'KHM 421' cenderung berukuran lebih kecil dibanding dua genotipe lainnya, sedangkan Phal. 'Salu Spot' x Phal. bellina '1102-38' memiliki daun yang 
Tabel 1. Rata-rata jumlah tunas, jumlah daun, jumlah akar, jumlah PLBs pada perlakuan perlakuan konsentrasi BAP populasi hibrida Phal. amabilis x Phal. 'KHM 421' pada 2 sampai 12 MST

\begin{tabular}{|c|c|c|c|c|c|c|}
\hline \multirow{2}{*}{$\begin{array}{l}\text { Konsentrasi } \\
\text { BAP }(\mu \mathrm{M})\end{array}$} & \multicolumn{6}{|c|}{ Jumlah tunas } \\
\hline & 2 & 4 & 6 & 8 & 10 & 12 \\
\hline 0.00 & 1.0 & 1.0 & 1.3 & $1.3 \mathrm{~b}$ & $1.3 \mathrm{~b}$ & $1.3 b$ \\
\hline 11.09 & 1.0 & 1.3 & 1.3 & $1.7 \mathrm{~b}$ & $1.7 \mathrm{~b}$ & $2.0 \mathrm{~b}$ \\
\hline 22.19 & 1.0 & 2.0 & 2.3 & $3.3 \mathrm{a}$ & $3.7 \mathrm{a}$ & $3.7 \mathrm{a}$ \\
\hline 33.29 & 1.0 & 1.3 & 1.7 & $1.7 \mathrm{~b}$ & $1.7 \mathrm{~b}$ & $1.7 \mathrm{~b}$ \\
\hline \multirow[t]{2}{*}{44.39} & 1.0 & 1.7 & 1.7 & $1.7 \mathrm{~b}$ & $2.0 \mathrm{~b}$ & $2.0 \mathrm{~b}$ \\
\hline & \multicolumn{6}{|c|}{ Jumlah daun } \\
\hline 0.00 & 2.7 & 3.3 & 3.7 & 3.7 & $3.7 \mathrm{c}$ & $3.7 \mathrm{c}$ \\
\hline 11.09 & 2.7 & 3.0 & 3.7 & 4.0 & $4.3 b c$ & $4.3 b c$ \\
\hline 22.19 & 3.7 & 4.0 & 4.7 & 5.3 & $6.3 \mathrm{a}$ & $7.0 \mathrm{a}$ \\
\hline 33.29 & 3.0 & 4.0 & 4.0 & 4.3 & $4.7 b c$ & $4.7 b c$ \\
\hline \multirow[t]{2}{*}{44.39} & 3.3 & 4.3 & 4.3 & 4.7 & $5.3 \mathrm{ab}$ & $5.3 b$ \\
\hline & \multicolumn{6}{|c|}{ Jumlah akar } \\
\hline 0.00 & 2.0 & 2.0 & 2.0 & 2.3 & 3.0 & $3.3 \mathrm{a}$ \\
\hline 11.09 & 1.0 & 1.7 & 1.7 & 1.7 & 1.7 & $2.0 \mathrm{~b}$ \\
\hline 22.19 & 1.7 & 2.0 & 2.0 & 2.0 & 2.0 & $2.0 \mathrm{~b}$ \\
\hline 33.29 & 1.3 & 1.3 & 1.7 & 1.7 & 1.7 & $1.7 \mathrm{~b}$ \\
\hline \multirow[t]{2}{*}{44.39} & 1.3 & 1.7 & 2.0 & 2.0 & 2.0 & $2.0 \mathrm{~b}$ \\
\hline & \multicolumn{6}{|c|}{ Jumlah PLBs } \\
\hline 0.00 & 0.0 & 0.0 & 0.0 & 1.0 & 1.0 & $1.0 \mathrm{~b}$ \\
\hline 11.09 & 0.0 & 0.0 & 0.0 & 2.3 & 3.0 & $3.7 \mathrm{a}$ \\
\hline 22.19 & 0.0 & 0.0 & 0.0 & 0.7 & 2.3 & $2.0 \mathrm{~b}$ \\
\hline 33.29 & 0.0 & 0.0 & 0.0 & 1.0 & 1.7 & $1.7 \mathrm{~b}$ \\
\hline 44.39 & 0.0 & 0.0 & 0.0 & 1.0 & 1.3 & $1.7 \mathrm{~b}$ \\
\hline
\end{tabular}

Keterangan: Rata-rata dengan huruf yang sama tidak berbeda nyata pada uji lanjut duncan multiple range test (DMRT) taraf $\alpha 5 \%$. $* / * *=$ nyata/sangat nyata; $\mathrm{tn}=$ tidak nyata

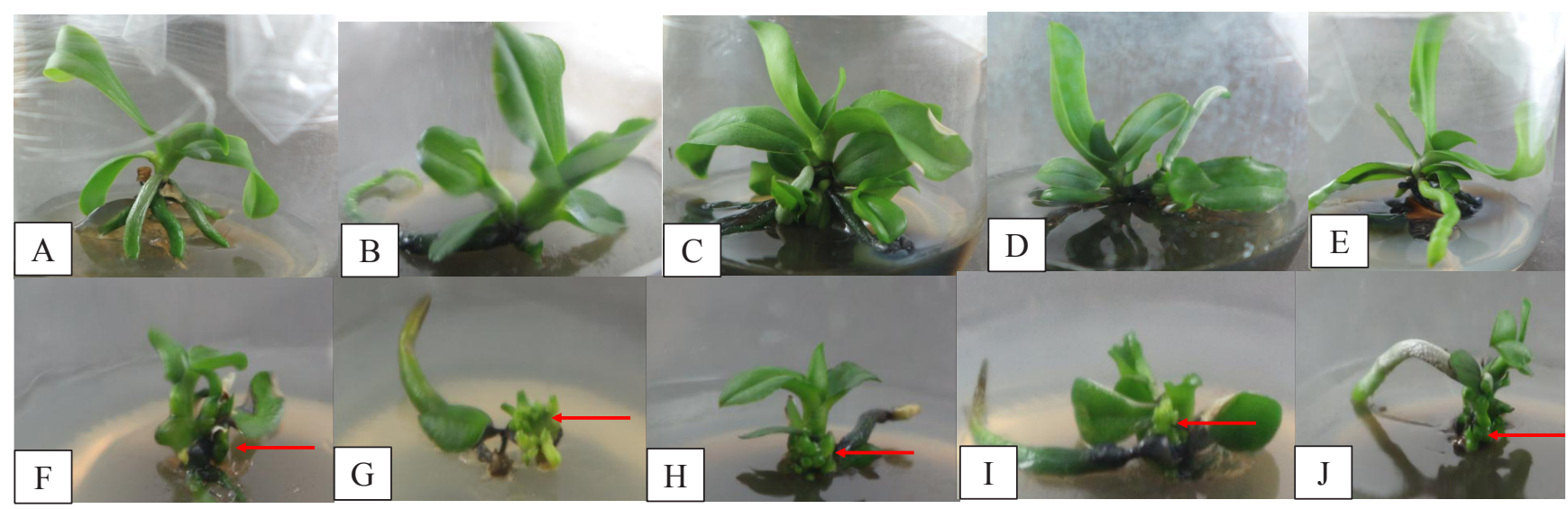

Gambar 1. Keragaan tunas (A-E) dan PLBs (F-J) Phal. amabilis $x$ Phal. 'KHM 421' pada berbagai media perlakuan BAP: A \& F) $0 \mu$ M, B \& G) $11.09 \mu \mathrm{M}, \mathrm{C} \&$ H) $22.19 \mu \mathrm{M}$, D \& I) $33.29 \mu \mathrm{M}$, E \& J) $44.39 \mu \mathrm{M}$. Tunas terbanyak di hasilkan pada perlakuan BAP $22.19 \mu \mathrm{M}(\mathrm{C})$. PLBs ditunjukkan oleh tanda panah, terbanyak pada perlakuan BAP $11.09 \mu \mathrm{M}(\mathrm{G})$ 
Tabel 2. Rata-rata jumlah tunas, daun, akar, dan PLBs pada perlakuan konsentrasi BAP pada Phal. 'Salu Spot' $x$ Phal. bellina '1102-38' pada 2 sampai 12 MST

\begin{tabular}{lcccccc}
\hline Konsentrasi BAP & \multicolumn{7}{c}{ Jumlah tunas } \\
\cline { 2 - 7 }$(\mu \mathrm{M})$ & 2 & 4 & 6 & 8 & 10 & 12 \\
\hline 11.09 & 1.0 & 1.3 & 1.3 & 1.7 & $1.7 \mathrm{~b}$ & $1.7 \mathrm{~b}$ \\
22.19 & 1.3 & 2.7 & 3.0 & 3.7 & $4.7 \mathrm{a}$ & $4.7 \mathrm{a}$ \\
33.29 & 1.3 & 1.3 & 1.7 & 2.3 & $2.3 \mathrm{~b}$ & $2.3 \mathrm{~b}$ \\
44.39 & 1.0 & 1.3 & 2.0 & 2.3 & $2.0 \mathrm{~b}$ & $2.3 \mathrm{~b}$ \\
\multicolumn{7}{c}{ Jumlah daun } \\
11.09 & 2.7 & 2.7 & 3.0 & $3.3 \mathrm{~b}$ & $3.7 \mathrm{~b}$ \\
22.19 & 2.3 & 2.7 & 5.7 & $6.3 \mathrm{a}$ & $7.0 \mathrm{a}$ \\
33.29 & 2.7 & 3.0 & 4.3 & 3.7 & $4.3 \mathrm{~b}$ & $5.0 \mathrm{~b}$ \\
44.39 & 1.7 & 2.0 & 3.3 & 3.3 & $3.7 \mathrm{~b}$ & $4.7 \mathrm{~b}$ \\
& 2.0 & 2.3 & 3.0 & \multicolumn{7}{c}{ Jumlah akar } & 3.3 & 3.3 \\
11.09 & 2.0 & 2.3 & 2.7 & 3.3 & 2.7 & 3.0 \\
22.19 & 1.3 & 1.3 & 2.0 & 2.3 & 2.7 \\
33.29 & 1.7 & 1.7 & 1.7 & 2.3 & 2.3 & 2.3 \\
44.39 & 1.7 & 1.7 & 2.3 & 2.3 & 2.3 & 2.3 \\
\hline
\end{tabular}

Keterangan: Rata-rata dengan huruf yang sama tidak berbeda nyata pada uji lanjut duncan multiple range test (DMRT) taraf $\alpha$ 5\%. $* / * *=$ nyata/sangat nyata; $\mathrm{tn}=$ tidak nyata

Tabel 3. Rata-rata jumlah tunas, daun, dan akar, pada perlakuan konsentrasi BAP pada Phal. 'Salu Spot' $x$ Phal. bellina '1102-44' pada 2 sampai 12 MST

\begin{tabular}{|c|c|c|c|c|c|c|}
\hline \multirow{2}{*}{$\begin{array}{l}\text { Konsentrasi BAP } \\
(\mu \mathrm{M})\end{array}$} & \multicolumn{6}{|c|}{ Jumlah tunas } \\
\hline & 2 & 4 & 6 & 8 & 10 & 12 \\
\hline 11.09 & 1.33 & 1.7 & $2.0 \mathrm{~b}$ & $2.0 \mathrm{~b}$ & $2.0 \mathrm{~b}$ & $2.0 \mathrm{~b}$ \\
\hline 22.19 & 1.33 & 2.7 & $3.7 \mathrm{a}$ & $4.7 \mathrm{a}$ & $5.7 \mathrm{a}$ & $6.0 \mathrm{a}$ \\
\hline 33.29 & 1.33 & 1.7 & $2.3 b$ & $2.7 \mathrm{~b}$ & $2.7 \mathrm{~b}$ & $3.3 \mathrm{~b}$ \\
\hline \multirow[t]{2}{*}{44.39} & 1.67 & 2.0 & $2.7 b$ & $3.0 \mathrm{~b}$ & $3.3 b$ & $3.7 \mathrm{~b}$ \\
\hline & \multicolumn{6}{|c|}{ Jumlah daun } \\
\hline 11.09 & 1.3 & 2.3 & 2.3 & 4.7 & 4.7 & $4.7 b$ \\
\hline 22.19 & 2.3 & 3.0 & 4.3 & 5.7 & 6.3 & $7.7 \mathrm{a}$ \\
\hline 33.29 & 1.7 & 2.3 & 3.0 & 4.3 & 5.0 & $5.3 b$ \\
\hline \multirow[t]{2}{*}{44.39} & 1.3 & 2.0 & 3.0 & 5.3 & 5.7 & $5.7 b$ \\
\hline & \multicolumn{6}{|c|}{ Jumlah akar } \\
\hline 11.09 & 1.0 & 1.0 & 1.3 & 1.3 & 1.3 & 1.3 \\
\hline 22.19 & 1.7 & 2.0 & 2.0 & 2.3 & 2.3 & 2.7 \\
\hline 33.29 & 1.0 & 1.0 & 1.0 & 1.7 & 1.7 & 2.0 \\
\hline 44.39 & 1.7 & 1.7 & 1.7 & 2.0 & 2.0 & 2.0 \\
\hline
\end{tabular}

Keterangan: Rata-rata dengan huruf yang sama tidak berbeda nyata pada uji lanjut duncan multiple range test (DMRT) taraf $\alpha 5 \%$. $* / * *$ nyata/sangat nyata; $\mathrm{tn}=$ tidak nyata

lebih panjang dan langsing dibandingkan Phal. 'Salu Spot' $\mathrm{x}$ Phal. bellina '1102-44' yang memiliki daun lebih oval. Pada penelitian ini, jumlah daun terbanyak juga dihasilkan pada media optimum untuk tunas, menunjukkan bahwa konsentrasi auksin $(0.53 \mu \mathrm{M}$ NAA) dan sitokinin (22.19 $\mu \mathrm{M}$ BAP) juga sesuai untuk pertumbuhan dan morfogenesis daun sehingga daun terbentuk sempurna dan tidak roset.

Jumlah akar pada Phal. amabilis x Phal.'KHM 421' terhambat oleh perlakuan BAP namun tidak berbeda nyata antar konsentrasi BAP, menunjukkan konsentrasi BAP pada 
level yang terendah sudah dapat menghambat inisiasi akar. Pada Phal. 'Salu Spot' x Phal. bellina '1102-38' dan Phal. 'Salu Spot' x Phal. bellina '1102-44' jumlah akar tidak berbeda nyata antar perlakuan konsentrasi BAP. Untuk mengetahui apakah BAP menghambat inisiasi akar pada kedua genotipe tersebut, perlu diuji pertumbuhan tunas pada media kontrol (tanpa BAP) dan media dengan perlakuan BAP. Peran auksin dalam mendorong pertumbuhan akar telah dijelaskan pada tanaman model oleh Aloni et al. (2006), dan khusus pada anggrek auksin umumnya dibutuhkan untuk induksi akar dan regenerasi planlet (Novak et al., 2014).

Meskipun dalam penelitian ini perlakuan ditujukan untuk induksi dan multiplikasi tunas aksilar, pada Phal. amabilis x Phal.'KHM 421' ternyata dapat terbentuk PLBs. Menurut Lee et al. (2013), PLBs identik dengan embrio somatik karena pola perkembangannya yang serupa dengan perkembangan embrio anggrek in vivo dan adanya hydroxyproline-rich glycoproteins (HRGPs) pada dinding sel PLBs seperti yang ditemukan pada embrio zigotik. Namun Fang et al. (2016) menjelaskan bahwa PLBs memiliki proses regenerasi yang tidak mengikuti pola embriogenesis yang ditunjukkan oleh adanya peran SHOOT MERISTEMLESS, sebuah gen KNOTTED-LIKE HOMEOBOX kelas I yang tidak ditemukan pada embriogenesis somatik umumnya. Kemampuan membentuk PLBs pada Phal. amabilis $\mathrm{x}$ Phal.'KHM 421' diduga karena tunas yang berasal dari perkecambahan biji masih memiliki sel-sel induk yang embriogenik atau protocormgenic sehingga mudah membentuk embrio dengan adanya induksi oleh auksin dan sitokinin.
Keragaman Genetik Tunas Klonal Phal. 'Salu Spot' $x$ Phal. bellina '1102-44' dengan Pto-SNAP Marker

SNAP adalah marka genetik yang dapat digunakan dalam mempelajari keragaman genetik spesies dan membantu dalam pengaplikasian studi asosiasi marka suatu sifat (Ong et al., 2015). Uji aplikasi marka SNAP untuk analisis keragaman dalam penelitian ini menggunakan klon Phal. 'Salu Spot' $x$ Phal. bellina, '1102-44' karena jumlah tunas yang dihasilkan pada genotype tersebut lebih banyak dari Phal. 'Salu Spot' $x$ Phal. bellina '1102-38'. Tunastunas dari Phal. amabilis x Phal.'KHM 421' tidak dapat digunakan karena berasal dari benih yang kemungkinan bersegregasi sehingga dapat menimbulkan bias tentang sumber keragaman pada tunas.

Hasil analisis dengan 11 set (reference and alternate) primer Pto-SNAP disajikan pada Tabel4. Hasil elektroforesis produk PCR, menunjukkan sebagian besar lokus SNAP berada dalam kondisi heterozigot, dan terdapat 2 tunas yang memiliki profil SNAP berbeda dari klon lainnya, yaitu tunas no. 16 dari perlakuan 22.19 $\mu \mathrm{M}$ BAP pada lokus Pto-241 dan tunas no. 19 dari perlakuan $44.39 \mu \mathrm{M}$ BAP pada Pto424 (Gambar 3). Persentase keragaman pada masing-masing lokus tersebut sebesar $7.7 \%$ dan $11.1 \%$. Hasil tersebut mengindikasikan terjadinya perubahan susunan basa DNA pada masing-masing planlet untuk masing-masing lokus tersebut.

Aplikasi marka SNAP berbasis gen Pto telah dilaporkan dapat membuktikan adanya variasi somaklonal pada planlet klonal asal PLBs dari Phal. amabilis. Raynalta

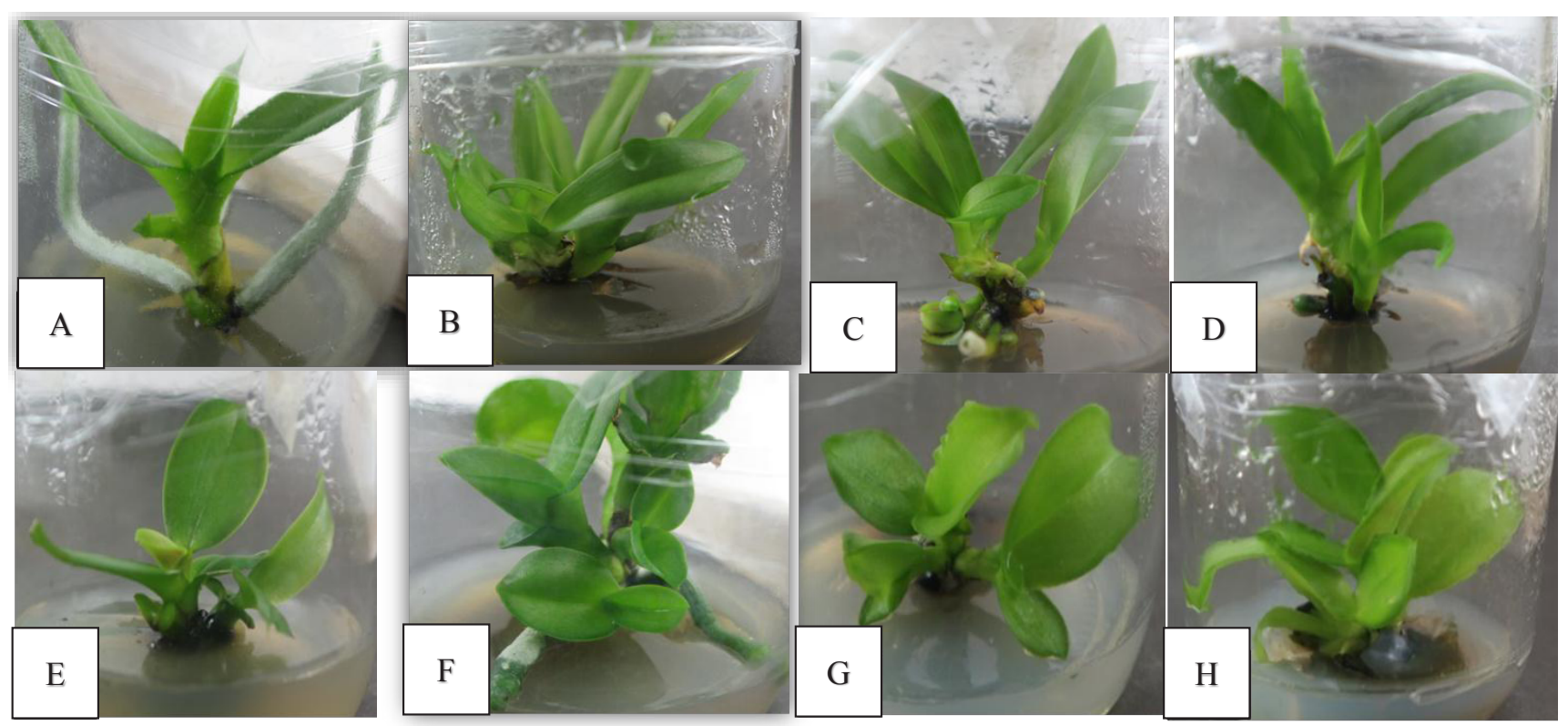

Gambar 2. Keragaan tunas Phal. 'Salu Spot' x Phal. bellina '1102-38' (A-D) dan Phal. 'Salu Spot' x Phal. bellina '1102-44' (E-H) pada berbagai media perlakuan BAP : A \&E) $11.09 \mu \mathrm{M}$, B \& F) $22.19 \mu \mathrm{M}, \mathrm{C} \&$ G) $33.29 \mu \mathrm{M}, \mathrm{D} \&$ H) $44.39 \mu \mathrm{M}$. Tunas terbanyak (B \& F) pada kedua genotipe dihasilkan pada perlakuan BAP $22.19 \mu \mathrm{M}$. 
et al. (2018) menganalisis keragaman pada 34 planlet klonal Phal. amabilis dengan 18 marka Pto-SNAP dan menunjukkan adanya variasi pada 3 lokus SNP dengan frekuensi mutasi $0.25 \%$. Penggunaan marka molekuler juga telah dilakukan oleh Khoddamzadeh et al. (2010) pada Phal. bellina menggunakan marka RAPD, dimana tidak terdapat perbedaan antara tanaman induk dengan PLBs setelah subkultur selama 3 bulan, namun setelah PLBs disubkultur kembali selama 6 bulan hasilnya menunjukkan terdapat disimilaritas sebesar 17\% dengan tanaman induknya. Hasil di atas menunjukkan tingginya peluang variasi somaklonal namun perlu dievaluasi lebih lanjut apakah perubahan pada tingkat molekuler tersebut akan menimbulkan fenotipik yang kurang menguntungkan pada tanaman sehingga tidak diperoleh tanaman yang 'true to type'.

Tabel 4. Persentase keragaman tunas klonal Phal. 'Salu Spot' x Phal. bellina '1102-44' berdasarkan analisis molekuler dengan Pto-SNAP marker

\begin{tabular}{lccc}
\hline $\begin{array}{l}\text { Konsentrasi BAP } \\
(\mu \mathrm{M})\end{array}$ & $\begin{array}{c}\Sigma \text { planlet } \\
\text { dievaluasi }\end{array}$ & $\begin{array}{c}\text { \% Keragaman } \\
\text { planlet }\end{array}$ & $\begin{array}{c}\text { Nomor tunas dan Pto-SNAP } \\
\text { sumber keragaman }\end{array}$ \\
\hline 11.09 & 4 & 0.0 & 0 \\
22.19 & 13 & 7.7 & $16($ Pto-241) \\
33.29 & 4 & 0.0 & 0 \\
44.39 & 9 & 11.1 & 19 (Pto-424) \\
Total & 30 & 18.8 & 2 planlet \\
\hline
\end{tabular}

$\mathrm{L}$

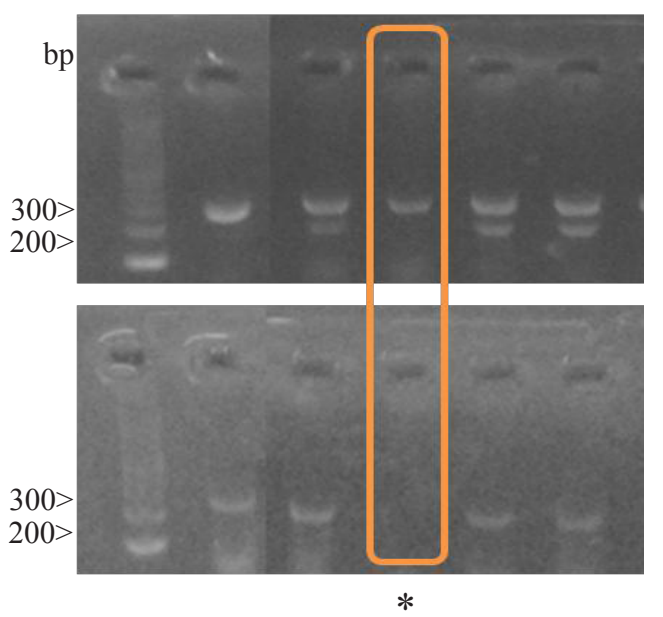

A
(Ref)

(Alt)

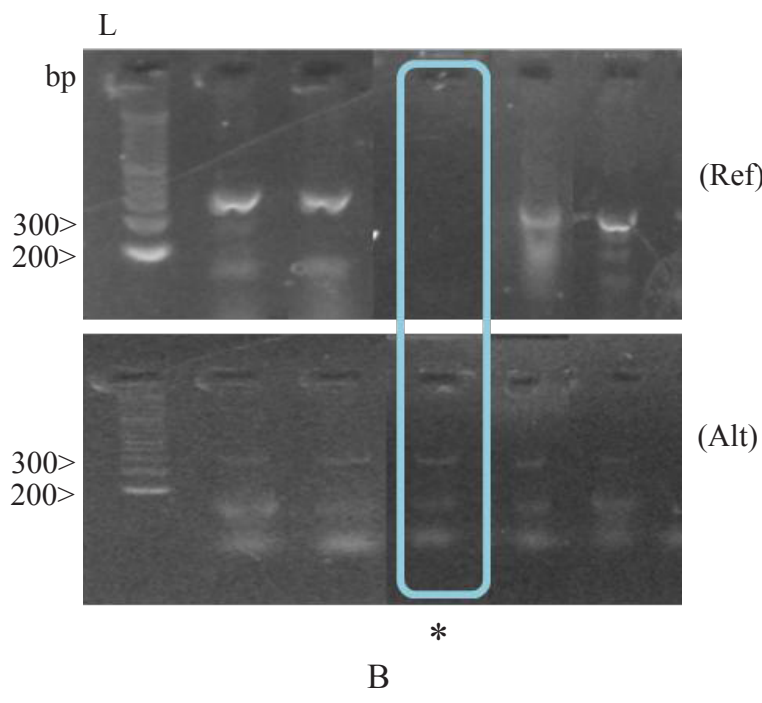

Gambar 3. Representasi hasil analisis molekuler klon Phal. 'Salu Spot' x Phal. bellina '1102-44' pada lokus SNAP Pto-241 (A), Pto-424 (B). *Nomor klon yang memiliki profil SNP berbeda dengan profil SNP mayoritas. L = ladder (100bp); Ref = alel reference; Alt $=$ alel alternative

\section{KESIMPULAN}

Konsentrasi BAP optimum untuk multiplikasi tunas dan jumlah daun pada ketiga genotipe hibrida yang diuji adalah 22.19 $\mu \mathrm{M}$ BAP, sedangkan pertumbuhan akar cenderung terhambat oleh perlakuan BAP. Phal.amabilis $\mathrm{x}$ Phal 'KHM 421' menghasilkan PLBs terbanyak pada 11.09 $\mu \mathrm{M}$ BAP, dua genotipe lainnya tidak membentuk PLBs. Marka Pto-SNAP berhasil mengidentifikasi keragaman pada tunas klonal Phal. 'Salu Spot' $x$ Phal. bellina '1102-44', yaitu menghasilkan 2 tunas dengan profil SNP berbeda dari tunas lainnya pada lokus Pto-241 dan Pto-424. Persentase keragaman tunas pada media perlakuan BAP $22.19 \mu \mathrm{M}$ sebesar $7.7 \%$ dan perlakuan BAP $44.39 \mu \mathrm{M}$ terdapat keragaman sebesar $11.1 \%$.

\section{DAFTAR PUSTAKA}

Aloni, R., E. Aloni, M. Langhans, M.C.I. Ullrich. 2006. Role of cytokinin and auxin in shaping root architecture: regulating vascular differentiation, lateral root initiation, root apical dominance and root gravitropism. Ann. Bot. 97:883-93. 
Bairu, M.W., A.O. Aremu, J.V. Staden. 2011. Somaclonal variation in plants: causes and detection methods. Plant Growth Regul. 63:147-173.

Balilashaki, K., R.Naderi, S. Kalantari, M. Vahedi. 2015. Efficient in vitro culture protocols for propagating Phalaenopsis 'Cool Breeze'. Plant Tissue Culture and Biotechnology 24:191-203. https://doi.org/10.3329/ ptcb.v24i2.23552.

Cetzal Ix, W., E. Noguera-Savelli. 2014. Oechidaceae: The Largest Family of Flowering Plants. http://www. eoearth.org/view/article/ $53725 \mathrm{e} 080 \mathrm{cf} 2 \mathrm{aafa} 2 \mathrm{ccd} 8 \mathrm{e} 15 /$.

Chen, J.T., C. Chang, W.C. Chang. 1999. Direct somatic embryogenesis on leaf explants of Oncidium Gower Ramsey and subsequent plant regeneration. Plant Cell Rep. 19:143-149.

Chen, J.T., W.C. Chang. 2001. Effects of auxins and cytokinins on direct somatic embryogenesis on leaf explants of Oncidium 'Gower Ramsey'. Plant Growth Reg. 34: 229-232.

Doyle, J.J., J.L. Doyle. 1987. A rapid DNA isolation procedure for small quantities of fresh leaf tissue. Phytochem Bull. 19:11-15.

Davies, P.J. 2004. Plant Hormones Biosynthesis, Signal Transduction, Action. Dordrecht: Kluwer Academic Publisher, USA.

Dwiyani, R. 2012. Mikropropagansi Tanaman Anggrek Vanda tricolor Lindl. Var. Suavis forma Bali yang membawa Gen KNOTTEDI-LIKE Arabidopsis thaliana (KNATI). Disertasi. Sekolah Pascasarjana. Universitas Gadjah Mada. Yogyakarta, ID.

Elina, J., D. Sukma, Giyanto, Sudarsono. 2017. Isolasi dan karakterisasi gen Pto asal 20 aksesi anggrek Phalaenopsis. J. Agron. Indonesia 45:204-211.

Fang, S.C., J.C. Chen, M.J. Wei, 2016. Protocorms and Protocorm-Like Bodies Are Molecularly Distinct from Zygotic Embryonic Tissues in Phalaenopsis aphrodite. Plant Physiol. 17:2682-2700.

Gow, W.P., J.T. Chen, W.C. Chang. 2009. Effect of genotype, light regime, explant position and orientation on direct somatic embryogenesis from leaf explants of Phalaenopsis orchids. Acta Physiol. Plant 31:363-9.

Handoyo, F., R. Prasetya. 2009. Native orchids of Indonesia. Indonesian Orchid Society. Jakarta, ID.
Jones, D., B. Tisserat. 1990. Clonal propagation of orchids. Methods Mol. Biol. 6:181-191.

Khoddamzadeh, A.A., U.R. Sinniah, M.A. Kadir, S.B. Kadzimin, M. Mahmood, S. Sreeramanan. 2010. Detection of somaclonal variation by random amplified polymorphic DNA analysis during micropropagation of Phalaenopsis bellina (Rchb.f.) Christenson. Afr. J. Biotech. 9:6632-6639.

Kosir, P., S. Skof, Z.Luthar. 2004. Direct shoot regeneration from nodes of Phalaenopsis orchids. Acta Agric. Slovenica 83:233-242.

Lee, Y.L., S.T. Hsu, E.C. Yeung. 2013. Orchid protocormlike bodies are somatic embryos. Am. J. Soc. Hortic. Sci. 100:2121-2131.

Mammadov, J., R. Aggarwal, R. Buyyarapu, S. Kumpatla, S. 2012. SNP markers and their impact on plant breeding. Internat. J. Plant Gen. 2012:728398. Doi:10.1155/2012/728398.

Novak, S.D., J.L. Luna, N.R. Gamage. 2014. Role of auxin in orchid development. Plant Signal. Behav. 9: e972277-1 - e972277-8.

Ong, P.W., I. Maizura, N.A. Abdullah, M.Y. Raffii, L.C. Oii. 2015. Development of SNP markers and their application for genetic diversity analysis in the oil palm (Elaeis guineensis). Genet. Mol. Res. 14:1220512216.

Paek, K.Y., E.J. Hahn, S.Y. Park. 2011. Micropropagation of Phalaenopsis orchids via Protocorms and ProtocormLike Bodies. In Clifton, N.J. (Ed.). Methods in Molecular Biology 710:293-306. Doi:10.1007/9781-61737-988-8_20.

Pusat Data dan Sistem Informasi Pertanian. 2015. Outlook Komoditas Pertanian Subsektor Hortikultura: Anggrek. Sekretaris Jenderal Kementrian Pertanian. Jakarta, ID.

Ramdan. 2011. Kultur daun dan pangkal batang in vitro anggrek bulan raksasa (Phalaenopsis gigantea J.J. Smith) pada beberapa media kultur jaringan. Skripsi. Departemen Agronomi Dan Hortikultura. Fakultas Pertanian. Institut Pertanian Bogor. Bogor

Raynalta, E., D. Sukma. 2013. Pengaruh komposisi media dalam perbanyakan protocorm-like bodies, pertumbuhan planlet dan aklimatisasi Phalaenopsis amabilis. J. Hort. Indonesia 4:131-139. 
Raynalta, E., J. Elina, Sudarsono, D. Sukma. 2018. Clonal fidelity of micro-propagated Phalaenopsis planlets based on assessment using eighteen Ph-Pto SNAP marker loci. Agrivita J. Agric. Sci. 40:390-402.

Restiani, R., E. Semiarti, A. Indrianto. 2016. Konservasi anggrek hitam (Coelogyne pandurata Lindl.) melalui mikropropagasi pada berbagai medium kultur. hal. 393-404. Prosiding Symbion. Yogyakarta 27 Agustus 2016.

Rittirat, S., K. Thammasiri, S. Te-chato, S. 2012. Effect of media and sucrose concentrations with or without activated charcoal on the plantlet growth of P. cornucervi (Breda) Blume \& Rchb. f. J. Agric. Technol. 8: 2077-2087.

Sukma, D., J. Elina, Giyanto, S. Sudarsono. 2017. Disease resistance breeding of Phalaenopsis spp. for tropical environment and molecular marker development for plant selection. Acta Hort. 1167:237-244. Doi: 10.17660/ActaHortic.2017.1167.36.

Sun, W.Y., W.Y. Zhao, Y.Y. Wang, C.C. Pei, W.C. Yang. 2011. Natural variation of Pto and Fen genes and markerassisted selection for resistance to bacterial speck in tomato. Agric. Sci. China 10:827-837. Doi:10.1016/ S1671-2927(11)60068-0.

Yulianti, Y., S.I. Aisyah, D. Sukma. 2016. Pengaruh bahan organik nabati dan hewani terhadap pertumbuhan protocorm-like bodies Phalaenopsis amabilis (L.) Blume. J. Hort. Indonesia 7:176-186.

Yuswanti, H., I.P. Dharma, Utami, I.W. Wiraatmaja. 2015. Mikropropagasi anggrek Phalaenopsis dengan menggunakan eksplan tangkai bunga. Agrotrop 5:161-166. 